\title{
光学材料として見たセラミックス
}

\author{
池末明生 \\ (財)ファインセラミックスセンター 材料技術研究所（４56-8587 愛知県名古屋市熱田区六野2-4-1）
}

\section{A Review of Ceramic Materials for Optical Applications}

\author{
Akio IKESUE \\ Material Research and Development Laboratory, Japan Fine Ceramics Center, \\ 2-4-1 Mutsuno Atsuta-ku, Nagoya, Aichi 456-8587
}

(Received October 24, 2001)

\begin{abstract}
Recently, various transparent ceramics with excellent optical properties have been synthesized by a new processing method. For example in 1993, we successfully fabricated polycrystalline Nd:YAG ceramics with the same optical properties as high-quality Nd:YAG single crystal by the Czochralski method. The ceramics produced had extremely low porosity (ca. $<1$ vol. ppm) and homogeneous structure. Furthermore, highquality YIG single crystals with low dislocation densities could also be fabricated by a modified sintering method. The optical quality of some ceramic materials is improved dramatically to level the same as that of high quality single crystals. In this paper, I will discuss these new fabrication techniques and the application of optical ceramics as luminous tubes, new laser materials, scintillators, and optical communication components.
\end{abstract}

Key Words: Transparent ceramics, Polycrystal, Single crystal, Sintering, Optical applications

\section{1. 緒 言}

我国のセラミックス産業は発展の一途にあり，市場規 模で1.8兆円，世界シェアの50\%以上を占めるに至ってい る。セラミックスはギリシャ語のケラモス(焼き物)が語源 となったもので, その範囲はガラス, セメント, 耐火 物, 陶磁器, 新素材等が含まれている.

セラミックスは一般的に乳白色を呈しており, 光学目 的には利用できないものと考えられてきた．光とセラ ミックスの接点は, Maiman博士がルビーレーザーを発 見1)したのとほぼ同時期である1959年のことである。

Coble博士はセラミックス中に存在する残留気泡(光散乱 源)が失透原因であることを提唱し, 原料調整方法や焼結 技術を改良することで透光性アルミナの合成に成功2)し た。この成果は高速道路やトンネルなどの照明用ナトリ ウム灯の放電管に応用され, 現状における数百万本/年に も達する利用量は人類に多大な恩恵をもたらした証拠と も言える。この開発を契機に赤外線透過材料としての $\mathrm{MgF}_{2}$ やスピネル, 光シャッター用途のPLZT ( $\left.\mathrm{PbLa}\right)$ $\left.(\mathrm{ZrTi}) \mathrm{O}_{3}\right)$, 放射線検出用シンチレーターなどが開発され ているが，それらの市場性が十分でなくまた単結晶と類 比できる高性能化技術が存在しなかったため, 透光性セ ラミックスの将来は明るいとは言い難い状況であった。

一方，レーザー技術に係わるセラミックスとしては 10
年ほど前に筆者が世界で始めて光学グレードのNd:YAGセ ラミックスを開発し単結晶と同等のレーザー発振 3 ), さら にはNdの高濃度化により単結晶以上の高効率発振や高い ビーム品質を提供できることを報告4-6) した。そその後，筆 者自身もセラミックスの固有特性の探索や新媒質開発を 行なってきたが, 本成果の発表を境に日本や海外の幾つ かの研究機関で類似する研究が活発に行なわれ，着目す べき成果も報告されるようになった。セラミックスから レーザー発振, そして高いビームコヒーレンシィー, さ らには高効率かつ大出力化などこれまでの材料技術の想 像を越えるオリジナリティーが日本から世界に発信でき たが，研究に留まらず産業界で広く活用されれば幸いで ある。

ところで本稿では，筆者が開発または開発途上のセラ ミックスを中心として, 光とセラミックスの接点となっ た透光性アルミナおよび光学分野への応用が期待される 幾つかの材料技術を紹介する.

\section{2. 透光性アルミナの開発}

周知のようにセラミックスはランダムな方位を持った 微細結晶からなる多結晶体で, 陶磁器のように白濁して いるのが一般的イメージである。透光性アルミナは前述 した Coble博士によって多結晶体でも光透過できることが 
実証 ${ }^{2)}$ され，ゼネラルエレクトリック $(\mathrm{GE})$ 社が透光性ア ルミナとして商品化したのが開発の契機になる。当時, 不透明であると考えられてきたセラミックス中に存在す る気泡を減少させ微構造を制御すると, 光透過機能を有 することが発見された. 現代ではその透光性アルミナが 高速道路の高圧ナトリウム灯用放電管に用いられ, 莫大 な生産規模に達している。しかし，今や透光性セラミッ クスがさほど珍しい技術ではなくなったことと，ナトリ ウム灯以外にはわずかな市場しかないせいか最近に至る までは活発な研究開発は行われていなかった。

Fig. 1は筆者が作製した透光性アルミナおよび一般の高 純度アルミナの外観写真を示している. 本透光性材料は 摺りガラス程度の透光性が感じられるものであるが, 通 常のアルミナセラミックスは全く光を透過できないため 開発当時は画期的なものであった.

Fig. 2は一般の高純度アルミナセラミックスと $250 \mathrm{ppm} の$ $\mathrm{MgO}$ 添加した透光性アルミナの組織写真である. 組織 制御しない高純度アルミナセラミックスでは焼結中の結 晶成長が進み, 粒子内部と粒界部に気孔(散乱体)が観察さ れる。一方，僅か $250 \mathrm{ppm} 9 \mathrm{MgO}$ 添加したアルミナでは 粒子サイズが小さくなり，かつ気孔はほぼ完全に除去さ れた組織となる。 $\mathrm{MgO}$ の添加により焼結途上のアルミナ の粒成長が抑制されることで, 粒界の移動速度と気孔の 移動速度を接近 $(\mathrm{MgO}$ を添加しないときは粒成長速度が圧 倒的に大きい)させることが可能となり，結果的にセラ ミックス中の残留気孔量を激減できるため光を透過させ ることができる。しかしながら, 本セラミックスは六方 晶系の結晶構造であることから, 可視領域での直線透過 率は僅か20～30\%程度しかない。 また，厚さ $1 \mathrm{~mm}$ 程度の 透光性アルミナの全透過率 (直線 + 拡散透過率) は90 95 \%であるので，内部ロスは約5～10\%/mmと見積ることが でき結晶構造以外の大きな散乱源の存在を示唆してい る。近年に至ってホットプレス装置の開発により,これ までの雲囲気制御したアルミナより近赤外〜赤外線領域 の特性は改善されたが, 単結晶と比較するとその特性差 は未だ歴然としている。

3. 固体レーザー用セラミックス

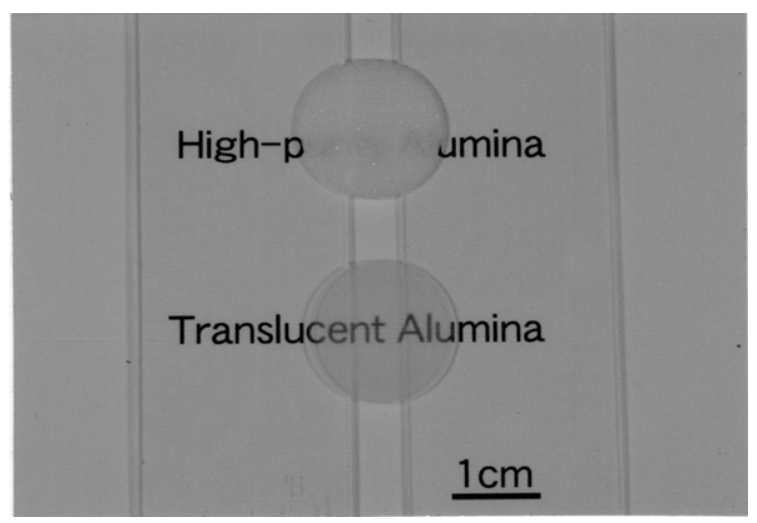

Fig. 1 Appearance of normal high-purity alumina, and translucent alumina.
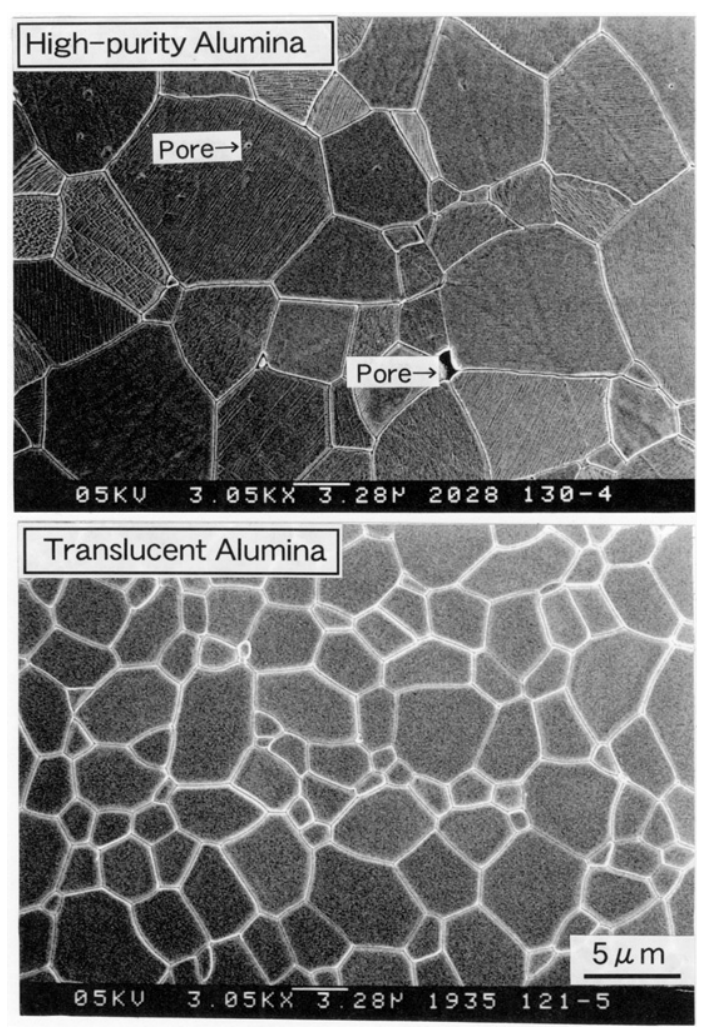

Fig. 2 Microstructure of normal high-purity alumina, and translucent alumina doped with 250 mass ppm of $\mathrm{MgO}$ by SEM.

\subsection{Nd:YAGセラミックス}

光増幅のできる多結晶体の開発はセラミック技術者の 夢であり，この夢は1991年(公表は1993年)に筆者らによ り実現3)された。前述したように多結晶セラミックス中に は光散乱を引き起す材料欠陥が存在し，技術的にこれら の散乱要因を除去することは不可能と考えられてきた。 1980年代にフィリップスのWithら ${ }^{7)}$, 無機材質研究所の関 田ら ${ }^{8)}$ が透光性YAGによるレーザー発振を試みたが, 光増 幅できるセラミックスの合成に至らなかったようであ る.これまでの透光性セラミックスは試料厚さが僅か 1 $\mathrm{mm}$ 程度でも不鮮明となっていたが, Nd:YAGセラミック スでは散乱係数がレーザー単結晶並みの $0.2 \% \mathrm{~cm}^{-1}$ 以下の 合成も可能であり, その厚さが数十 $\mathrm{mm} レ$ ベルに至っても 文字を鮮明に判読できる。

Fig. 3はYAG単結晶を育成する際に添加する発光イオン のイオン半径と偏析係数の関係を示した. 偏析係数の大 きさは発光イオンが母結晶中への取り込まれ易さを示す もので，この值が小さいほど結晶中に取り达まれ難いこ とを意味する。レーザーに活用されるNdのYAGへの偏析

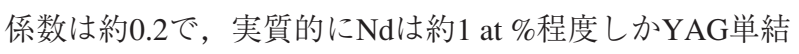
晶中に均一固溶できない. ところがYAGセラミックス中 には単結晶の約 10 倍の Ndを導入することが可能である. 1 at $\% \mathrm{Nd}: \mathrm{YAG}$ 単結晶の ${ }^{4} \mathrm{~F}_{5 / 2}$ バンドに対する吸収係数は8.5 $\mathrm{cm}^{-1}$ であるが, Nd:YAGセラミックスは〜 $85 \mathrm{~cm}^{-1}$ までを自 由に設定できる。このことは半導体レーザー $(\mathrm{LD})$ 光の吸 収効率が向上するため, 例えばマイクロチップレーザー の高効率化達成に貢献できることを意味する. 


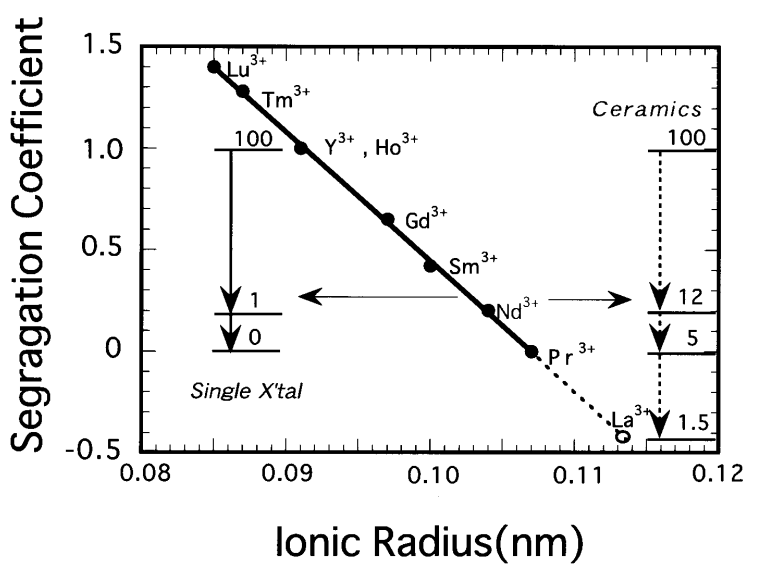

Fig. 3 Relationships between segregation coefficients of fluorescence ions and solid-solution content in YAG crystal.

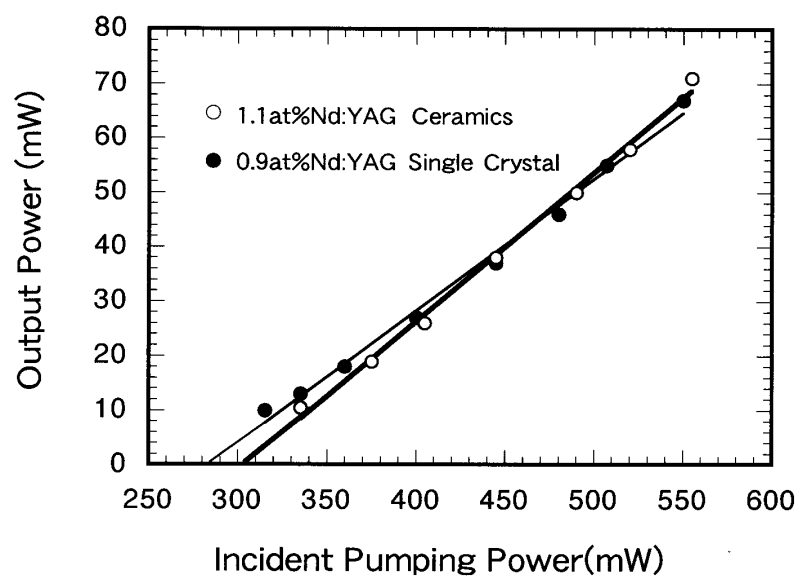

Fig. 4 Laser input energy for 0.9 at\% Nd:YAG single crystal and polycrystalline 1.1 at $\%$ Nd:YAG ceramics excited by $808 \mathrm{~nm}$ diode laser.

Fig. 4はNd濃度がほぼ同一のYAG単結晶とセラミックス を波長 $808 \mathrm{~nm}$ のLDで励起したときのcw発振特性を示し た。セラミックスの発振の閾值は単結晶より若干大きい が，スロープ効率は28\%に達し，同じ配置で発振実験を 行った単結晶の $24 \%$ を超えるものとなっている。セラ ミックスのNd濃度が単結晶のそれより $0.2 \%$ 高いため，高 いゲインが得られたためである。セラミックスの粒界近 傍には多数の転位が存在するので，この領域は著しい散 乱を引き起すものと考えられてきた。殆ど散乱を生じな い粒界の本質について科学的見解はでていないが，少な くとも粒界付近に第二相の存在がなく, さらに転位密度 が小さく(屈折率変動が極めて小さく)かつ転位発生領域が 発振波長に比べ著しく狭い条件は満たしているはずであ る.

Fig. 5は4.8 at \%Nd:YAGセラミックスのTEM(Transmittion Electron Microscopy)による粒界構造を示している．写真中 央付近が構成粒子間の粒界に相当するが，ほぼ粒界まで 格子像が形成され粒界相等は観察されていない。粒界散 乱は粒界相の問題以外に粒界近傍に発生した転位による 密度 (屈折率) 変動もその要因のであるが, 前述した転位発 生による屈折率変動が小さくまたその変動領域が発振波

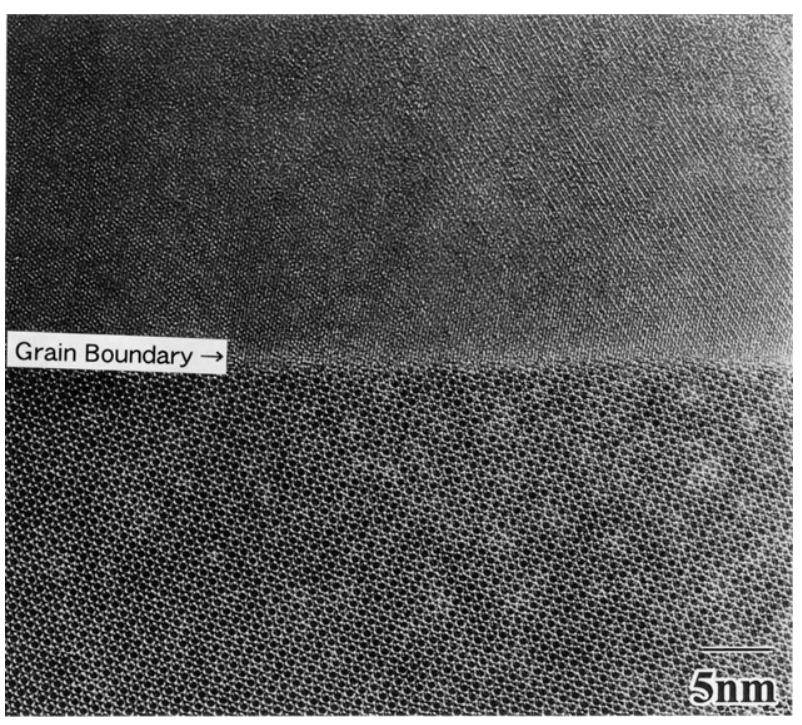

Fig. 5 TEM photograph of 4.8 at $\%$ Nd:YAG ceramics near grain boundary.

長に比べて非常に狭いという条件を試料全体に渡ってク リアしている理由により，ビーム品質および発振効率の 高いレーザーを得ているものと考えられる。

\subsection{Nd: $\mathrm{Y}_{2} \mathrm{O}_{3}$ セラミックス}

$\mathrm{Y}_{2} \mathrm{O}_{3}$ は有望なレーザーホストとして注目される材料で あるが，その融点が $2400^{\circ} \mathrm{C}$ であり融点直下の $2280{ }^{\circ} \mathrm{C}$ に六 方晶 $\Leftrightarrow$ 立方晶の相転移点が存在 ${ }^{9)}$ するため, 基本的に従来 の溶融凝固法で良質の単結晶を得ることは出来ない。本 材料の合成をセラミックス技術で達成できれば， Nd:YAG に続く第二のセラミックスレーザーとなり得る。 $\mathrm{Y}_{2} \mathrm{O}_{3}$ セ ラミックスの透明化に関してはGreskovichら10)により10 $\mathrm{mol} \% \mathrm{ThO}_{2}-\mathrm{Y}_{2} \mathrm{O}_{3}$ 系で $2200{ }^{\circ} \mathrm{C}$ で長時間焼結することで実現 されているが，放射性物質の添加の危険性と結晶欠陥お よび超高温焼結による安定製造やコスト的問題が指摘さ れている。純粋なかつ透明な $\mathrm{Y}_{2} \mathrm{O}_{3}$ 焼結体の製造技術と レーザー特性に関する研究は途についたばかりの状況で あるが，既にレーザー素子としての可能性が高いデータ が得られつつある。

Fig. 6 は $1700{ }^{\circ} \mathrm{CにてHIP}$ 処理 (圧力は98MPa) したNd: $\mathrm{Y}_{2} \mathrm{O}_{3}$ セラミックスの外観写真を示している。試料サイズは $33 \times$ $33 \times \mathrm{t} 3 \mathrm{~mm}^{3}$ であり，透明でかつ偏光板を通して複屈折も 殆ど観察できない良質のセラミックスが得られている。 現在のところ, 透明な $\mathrm{Nd}: \mathrm{Y}_{2} \mathrm{O}_{3}$ セラミックスの合成はHIP などの高圧焼結技術が必要であるが， $1700 １ 800{ }^{\circ} \mathrm{C}$ 常 圧焼結でも透明セラミックスを作製することは可能にな りつつある。

Fig. 7はNd: $\mathrm{Y}_{2} \mathrm{O}_{3}$ セラミックスの吸収スペクトルおよびベ ルヌイ法で作製したNd: $\mathrm{Y}_{2} \mathrm{O}_{3}$ 単結晶の透過率のバックグラ ウンドレベルを示した. Nd添加に伴う鋭い吸収ピークが 観察され，またその ${ }^{4} \mathrm{~F}_{5 / 2}$ バンドにおける吸収線幅 $\Delta \lambda$ は 1.1 $\mathrm{nm}$ ，吸収係数はYAGの1.6倍の $13.9 \mathrm{~cm}^{-1}$ である. $\mathrm{Y}_{2} \mathrm{O}_{3}$ セラ ミックスへは殆どのランタニド希土類元素添加が可能で あり, YAGのように偏析係数の極端に小さな元素(例えば $\mathrm{Nd}$ )がないため添加量の選択幅は極めて広い。さらに, 


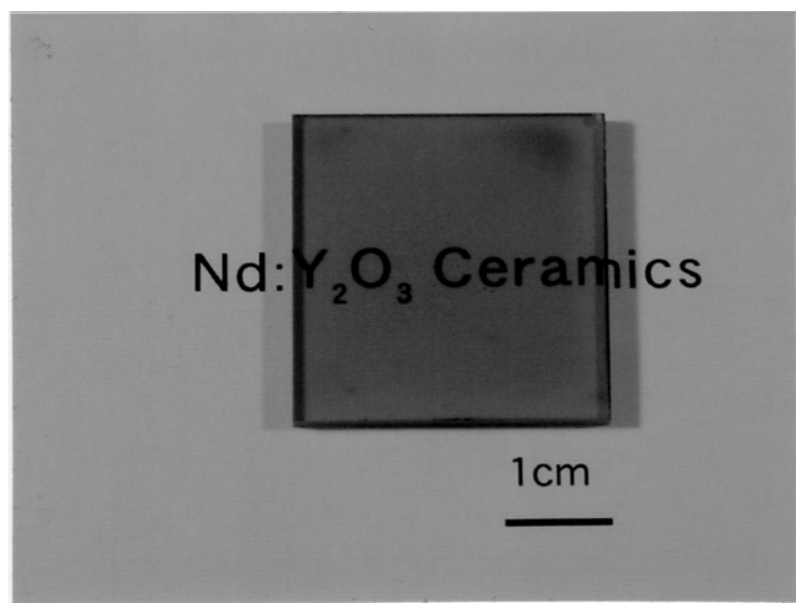

Fig. 6 Appearance of transparent $\mathrm{Nd}$ doped $\mathrm{Y}_{2} \mathrm{O}_{3}$ ceramics by HIP.

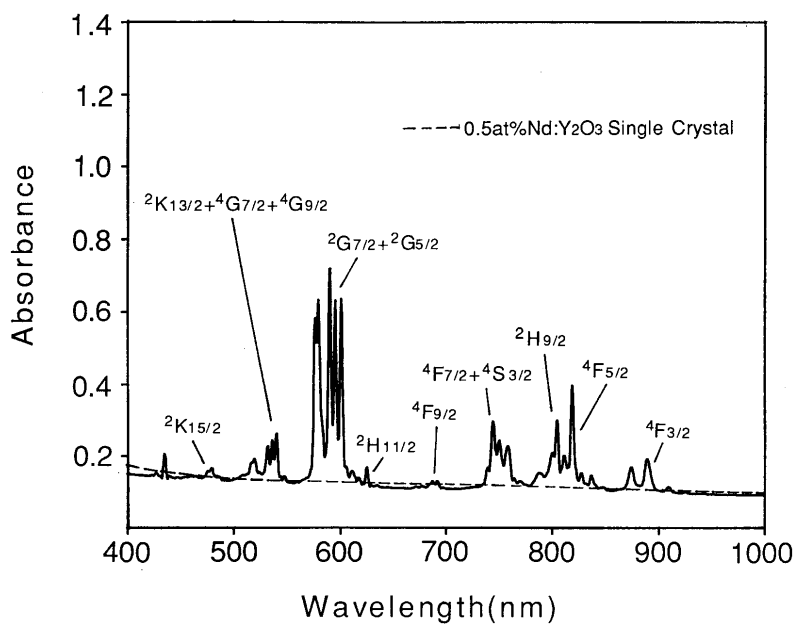

Fig. 7 Absorption spectra of $\mathrm{Nd}$ doped $\mathrm{Y}_{2} \mathrm{O}_{3}$ ceramics, and background level of $\mathrm{Nd}$ doped $\mathrm{Y}_{2} \mathrm{O}_{3}$ single crystal by Verneuil method between visible and near-infrared wavelength region.
$\mathrm{Y}_{2} \mathrm{O}_{3}$ の熱伝導係数は $27 \mathrm{~W} / \mathrm{mK}$ ( $\mathrm{YAG}$ の 2 倍以上) と報告 ${ }^{11) さ ~}$ れており，ハイパワーレーザーとしても有望と考えられ る。筆者が作製した $\mathrm{Nd}: \mathrm{Y}_{2} \mathrm{O}_{3}$ セラミックスには僅かな気孔 が存在するため高効率のレーザー発振には至っていない が，近い将来にYAGと競合する新媒質が創製されること

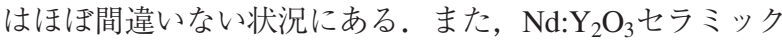
スの発光中心波長は1078 nmであり，本波長带での蛍光強 度はNd:YAGの1/2〜1/3程度である。しかし，950 nm帯で は逆に2 3倍の発光強度が得られており, ハイパワーブ ルーレーザーの可能性 ${ }^{12)}$ 秘めている。

\section{4. 放射線検出用セラミックス}

シンチレーターはX線, $\gamma$ 線等の放射線照射により発光 する物質であり，その用途はX線 C T ( Computed Tomography) やPET (Positron Emission Tomography) を始め とする医療分野，高エネルギー物理や非破壊検査などで ある。

X線CT用固体検出器の原理であるが，X線などの放射線 が入射するとシンチレーター(蛍光物質)が励起され，入射 光強度に比例した発光が生じる。この発光をフォトダイ オードまたは光電子増倍管の受光素子がセンシングし, 発光強度に比例した電気信号に変換されて放射線を検出 することができる。シンチレーター材料はB G O $\left(\mathrm{Bi}_{4} \mathrm{Ge}_{3} \mathrm{O}_{12}\right), \mathrm{GSO}\left(\mathrm{Ce}: \mathrm{Gd}_{2} \mathrm{SiO}_{5}\right), \mathrm{CWO}\left(\mathrm{CdWO}_{4}\right)$ などが挙 げられるが，それらは全て単結晶材料であった。また， シンチレーターの具備特性として, (1)検出感度が高いこ と (2)応答速度が早いこと(3)放射線による劣化が少ないこ と (4)フォトマルとの波長感度が一致していることなどが 挙げられるが，この分野もセラミックス化の波が押し寄 せている。

Table 1は代表的な単結晶およびEu: $(\mathrm{Y}, \mathrm{Gd})_{2} \mathrm{O}_{3}, \quad \mathrm{Pr} \mathrm{Gd}_{2} \mathrm{O}_{2} \mathrm{~S}$ セラミックス系のシンチレーター特性を比較13)している。

Table 1 Comparison of some physical properties of single crystal with ceramics for solid-state scintillator.

\begin{tabular}{|c|c|c|c|c|}
\hline & TI:CsI & $\mathrm{CdWO}_{4}$ & $\mathrm{Eu}:(\mathrm{Y}, \mathrm{Gd})_{2} \mathrm{O}_{3}$ & $\operatorname{Pr}: \mathrm{Gd}_{2} \mathrm{O}_{2} \mathrm{~S}$ \\
\hline Type & Single Crystal & Single Crystal & Ceramics & Ceramics \\
\hline Structure & Cubic & Monoclinic & Cubic & Hexagonal \\
\hline Density $\left(\mathrm{g} / \mathrm{cm}^{3}\right)$ & 4.53 & 7.90 & --- & 7.34 \\
\hline $\begin{array}{l}\text { Emission } \\
\text { Muximum (nm) }\end{array}$ & 550 & 480 & 610 & 510,670 \\
\hline $\begin{array}{l}\text { Decay Time } \\
\text { ( } \mu \mathrm{sec})\end{array}$ & 1 & 5 & 1000 & 3 \\
\hline Afterglow & $0.5 \% / 3 \mathrm{msec}$ & $0.005 \% / 3 \mathrm{msec}$ & $<0.1 \% / 100 \mathrm{msec}$ & $0.1 \% / 1 \mathrm{msec}$ \\
\hline Sensitivity & 3.5 & 1.0 & 2.5 & 1.8 \\
\hline
\end{tabular}


GE社で開発された ピーク波長が $610 \mathrm{nmでX}$ 線に対する感度はCWOの2.5倍に 達している。セラミックス検出器を搭載したX線CTとし て世界で初めて実用化されたが, 発光減衰時間が $100 \mathrm{msec}$ と長く, 高速の放射線検出には不適である。

$\mathrm{Eu}:(\mathrm{Y}, \mathrm{Gd})_{2} \mathrm{O}_{3}$ セラミックスの透過率14) は, 試料厚さ 1.5 $\mathrm{mm}$ で65〜 70\% (散乱は約 $15 \% / \mathrm{mm}$ )であり理論量(約 $80 \%$ ) に遠く及ばない状況である。一方， $\mathrm{Pr}_{2} \mathrm{Gd}_{2} \mathrm{O}_{2} \mathrm{~S}$ 系セラミッ クス ${ }^{15,16)}$ は検出感度としては若干前述のセラミックスに 劣るが，蛍光減衰時間が大幅に改良され高応答性のシン チレーターとして着目されている. 日立メディコ社が我 国でX線CT用に実用化 ${ }^{16)}$ しているが，本材料はさらに光 散乱が大きく(散乱は40～ $50 \% / \mathrm{mm})$, 高エネルギー $\gamma$ 線な どの試料厚さが必要とされる用途に対しては特性改良の 必要13)があると述べている。

Fig. 8は筆者が開発した電子線検出用のCe:YAGシンチ レーターの透過特性 ${ }^{17)}$ および電子線照射時の検出画像17) である，試料の透過率は理論量に達し， $\mathrm{Ce}^{3+}$ インによる $550 \mathrm{~nm}$ 帯での強い蛍光が観察できる. また, $6.5 \times 9.0 \mathrm{~mm}$ エリアに6 kVの加速電子を照射したときの蛍光画像を CCDカメラで捕えたものであるが, 完全に残留気孔を除 去したCe:YAGセラミックスは蛍光ムラのない均一な画像 が得られている。筆者の電子線検出用シンチレーターセ ラミックスはTEM, SEM(Scanning Electron Microscopy)や
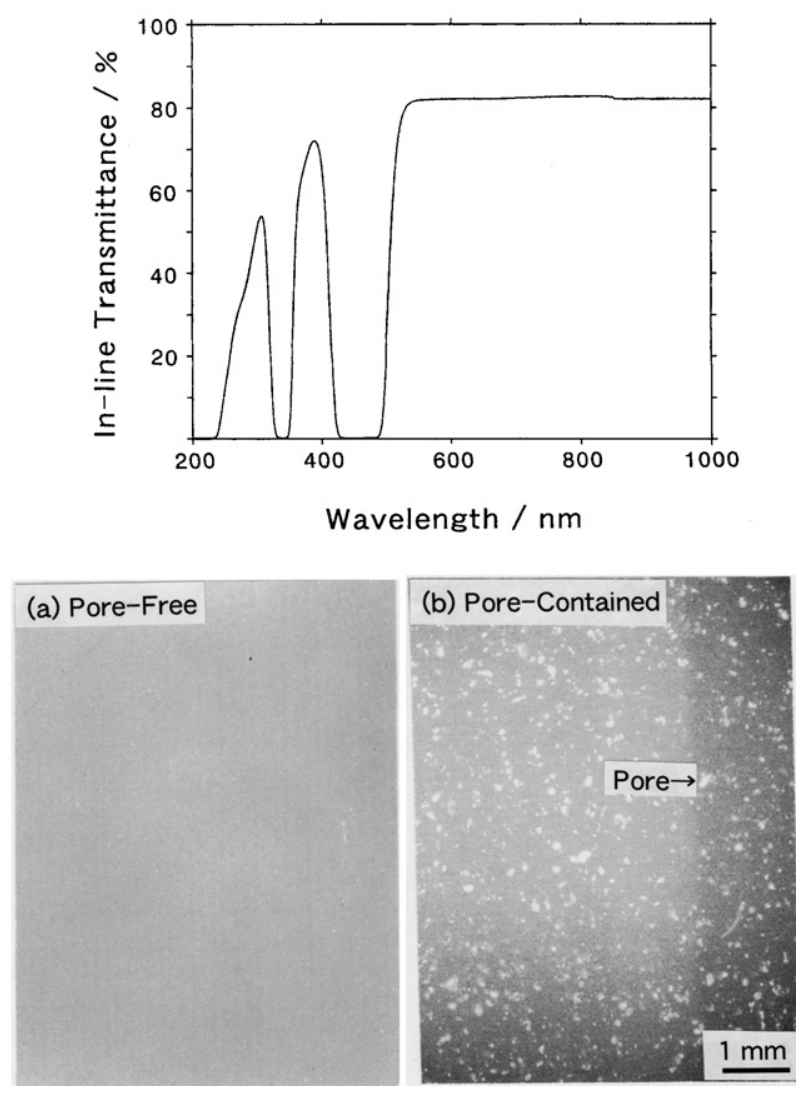

Fig. 8 Transmission spectrum (upper figure) and the detected image (lower photographs) irradiated by electron beam of Ce:YAG ceramics scintillator. Although we can observe heterogeneous luminescence in porecontained specimen, luminescence image of pore-free Ce:YAG ceramics is extremely fine.
イメージインテンシファイヤーなどに有用である. 本品 の用途開発は始まったばかりであるが, 前述した固体 レーザーに貢献した多結晶セラミックスの透明化技術, 後述のアイソレーター開発における単結晶化技術が本分 野の基礎技術として貢献する可能性が高い.

\section{5. 光通信用セラミックス}

\section{1 光シャッター}

光通信分野にもセラミックスの適用が検討されてい る. 1970年にG. H. Haertlingら ${ }^{18)} に よ り$ 開発されたPLZT ( ( PbLa) $(\mathrm{ZrTi}) \mathrm{O}_{3}$ でPb/La/Zr/Ti比は91/9/65/35が一般的) は 当初戦闘機に搭乗するパイロットの爆撃に際しての閃光 防御眼鏡として応用が検討されてきたが，その後光通信 用途としての導波路型光スイッチ或いはカメラの高速 シャッターとして着目されるようになった。 (Fig. 9，10は 新居浜工業高等専門学校の中山助教授の御好意による。)

Fig. 9はPLZTセラミックスの外観写真および本セラミッ クスを用いた光シャッターの応用19)である. 本材料は基 本的に正方晶系のPZT $\left(\mathrm{Pb}(\mathrm{ZrTi}) \mathrm{O}_{3}\right)$ にLaを添加すること で, 立方晶系の結晶構造に接近させ, かつ電気光学効果 を付与させたものである. 試料は約 $0.5 \mathrm{~mm}$ 厚さであはる が可視領域では透明であり，このサンプルに200〜300 Vの 電圧をかけると, 写真 $(\mathrm{b})$ に見られるようなシャッター機 能(すなわち, 電気光学効果であり, 材料に比較的高い電 圧を印加することで光変調を行なう. 半波長電圧以下で
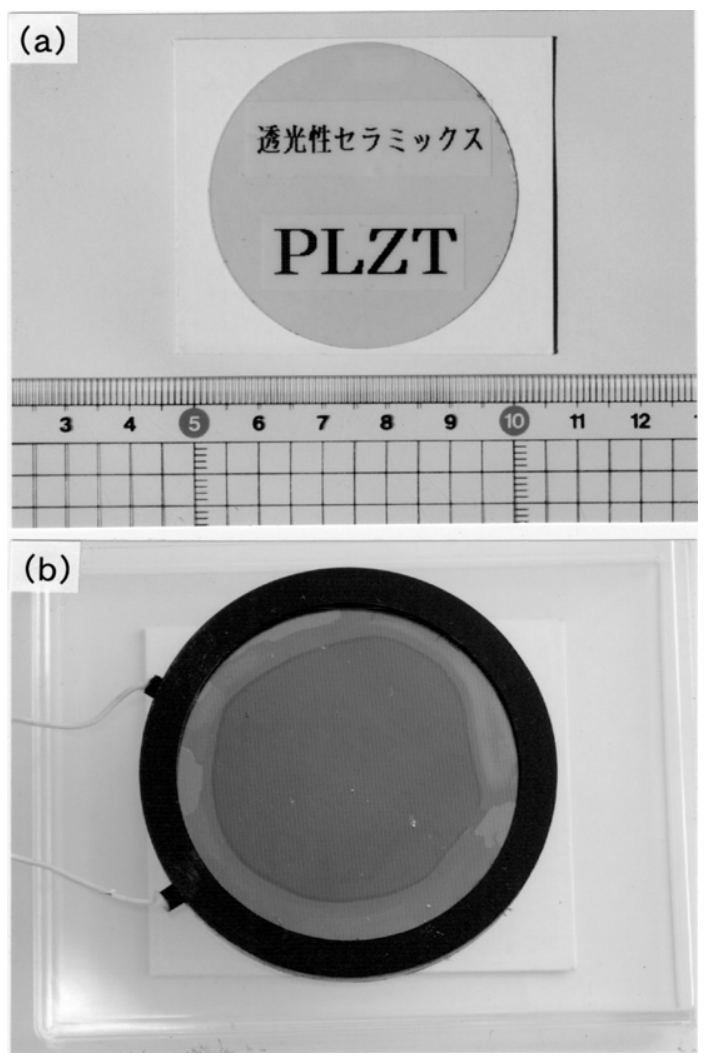

Fig. 9 Appearance of transparent PLZT ceramics (a). We can observed opto-elecrtical effect as optical shutter, when electrical high voltage held at PLZT ceramics through electrode. 
あると電圧の強弱で光変調が可能となり，それ以上では 透過光の色調が可変となる)が現れる.

Fig. 10は厚さ $0.5 \mathrm{~mm}$ のLZTセラミックスの透過スペク トルを示した。PLZTの屈折率は2.5であるので，表面の反 射損失は約 $33 \%$ となり，本材料の理論透過率は67\%とい うことになる。本試料の透過率は理論量付近に達してお り, 挿入損失は $2.5 \mathrm{~dB}$, 消光比は約 $20 \mathrm{~dB}$ という值が得ら れている.

ところで, PLZTは液晶と比べ応答速度は早いものの作 動電圧が高い欠点があり，今のところ民生利用には至っ ていない.しかしながら, 高速動作 $(50$ usec $)$ は非常に魅 力があり，将来の技術ニーズによっては本材料が見直さ れる可能性もあり得る。

\section{2 アイソレーター}

近年の大容量情報伝送ニーズを背景とした光ファイ バー網整備に伴い，磁気光学(ファラデー)効果を応用した アイソレーター製品の需要が増大している。一般的にア イソレーターにはYIG $\left(\mathrm{Y}_{3} \mathrm{Fe}_{5} \mathrm{O}_{12}\right)^{20)}$ またはBi置換希土類鉄 ガーネット単結晶 ${ }^{20)}$ が用いられている。アイソレーター 単結晶の両端面には偏光子が設置されており, 順方向か ら入射した半導体レーザー光がアイソレーター結晶を通 過すると 45 度偏光して光ファイバーを伝送する。また， 光ファイバーを伝送した反射波が逆方向からアイソレー ター中に侵入・透過するとさらに 45 度 (往復で 90 度) 偏光 するので，順方向側の偏光子を予め90度回転させておけ ば戻波をシャットアウトできる。ところで，このアイソ レーター結晶はFZ (Floating Zone) 法 ${ }^{21)}$ PLPE (Liquid Phase Epitaxitial) 法21)で製造された単結晶のみしか利用できな かったが，セラミックス技術で単結晶を作製することも 可能となりつつある.

Fig. 11はセラミックス技術を用いた単結晶の育成原理の 一つを示した。高精度に研磨した種子結晶(YIG単結晶)と 不連続粒成長を起す多結晶体 (YIGセラミックス)を熱間接 合し，この状態を維持したまま熱処理することで目的が 達成できる。種子結晶と多結晶体を接合し熱処理したと き，両者の界面に着目すると種子結晶の表面エネルギー

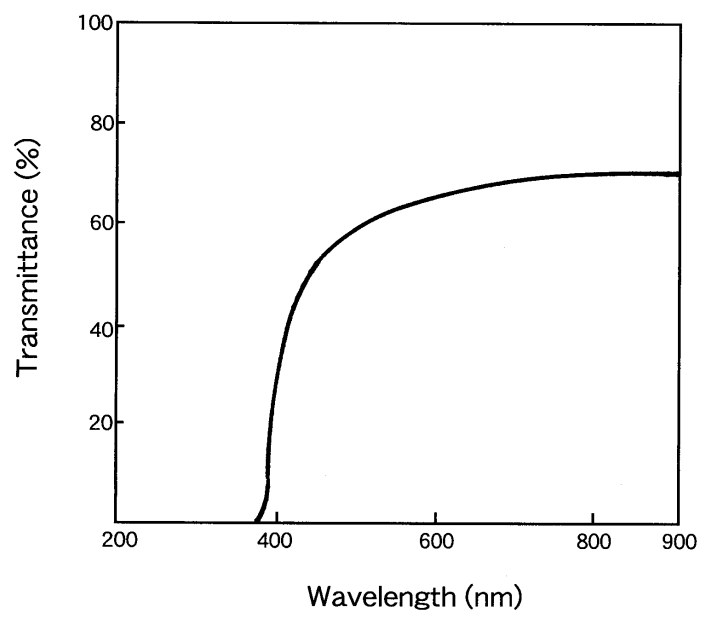

Fig. 10 Transmission spectrum of PLZT ceramics between visible and near-infrared wavelength region.
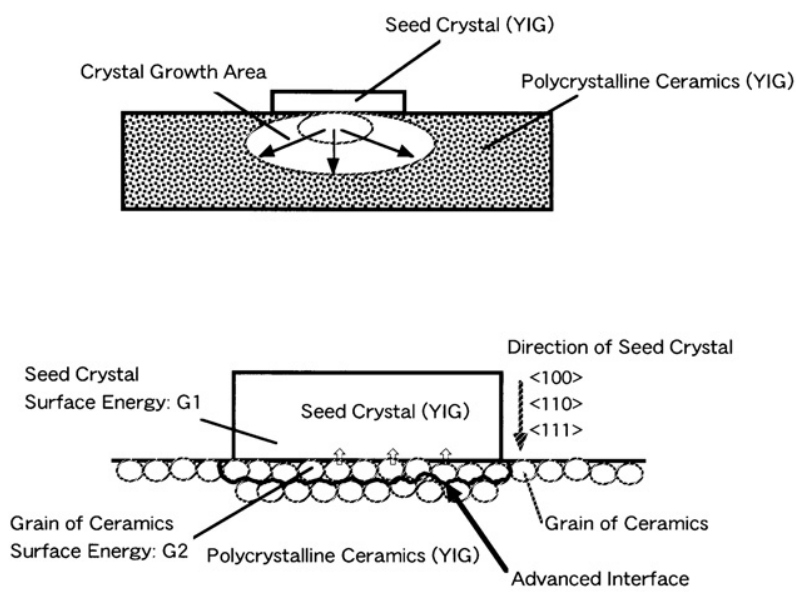

【Important Role】

G1 $<$ G2 $\rightarrow$ Migration : Seed-Grain Interface

Fig. 11 Principle for single crystallization by sintering method.

は多結晶体の個々の粒子(せいぜい，10 $\mu \mathrm{m}$ 以下)に比べ圧 倒的に低いので，安定な方向に収束するという物質の性 質を利用すれば，種子結晶と接する微結晶は順次粗大結 晶(単結晶)に併合されて行き，一定温度と時間を与えるこ とで全体を単結晶化することができる。

Fig. 12はYIGセラミックス (多結晶体) に出力数Wクラス の $\mathrm{CO}_{2}$ レーザーを短時間照射して結晶成長の起点(粗大結 晶の形成)を設け，さらに熱処理することで単結晶化途上 にある試料の微構造写真である。写真右上が多結晶セラ ミックスで見られる粒界の存在する構造であり，左下の 方向から粒界のない単結晶を成長させている状態を示し ている. 本技術では直径1 2 亿ンチ以上の単結晶も合成 可能22)であり，結晶成長速度は $0.5 \sim 1.0 \mathrm{~mm} / \mathrm{h}$ 程度に達し ている。得られた単結晶中には亜粒界はなく，転位密度 も $10^{2} / \mathrm{cm}^{2}$ 程度であり FZ法で作製した市販の同単結晶のそ の值， $10^{7} / \mathrm{cm}^{2}$ に比べても圧倒的に低いものであった．本 研究の詳細は別途報告するが, 磁気光学特性は従来の溶

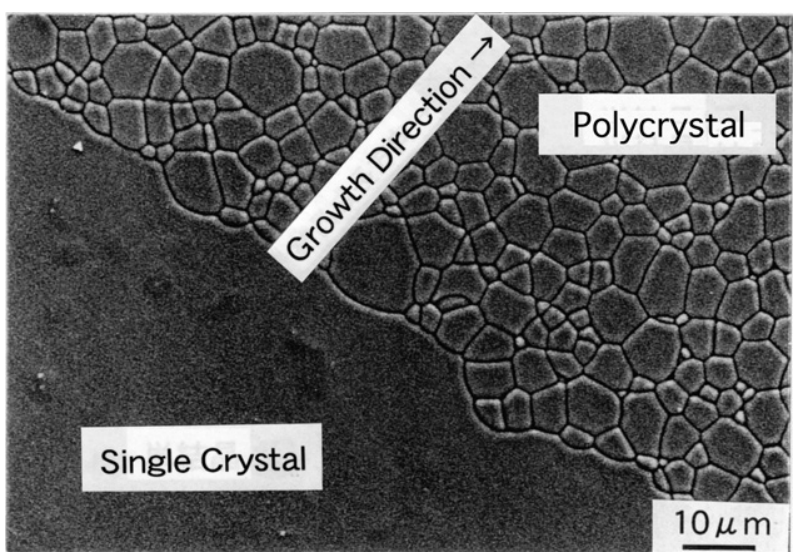

Fig. 12 Structure change from polycrystalline YIG ceramics to YIG single crystal. YIG single crystal grow toward to the growth direction as shown in this figure. 
融凝固法で作製された単結晶と類似しており，七ラミッ クスの固有特性が見つかれば従来の単結晶市場を脅かす 技術に発展する可能性がある。

また，本技術はアイソレーターだけに限定されるもの ではなく，携帯電話などのSAW (Surface Acoustic Wave)デ バイス用, 非線形光学材料, 強磁性材料, さらには熱電 や発光素子などに期待される金属間化合物, 電子材料な ど多方面の応用が考えられる。

\section{6. まとめ}

透光性セラミックスは固体レーザー技術と時を同じく して生まれたもので, 約40年の技術史をもっている。透 光性セラミックスは1960年代のような単純な拡散透過性 から筆者が実現したコヒーレンス光の媒質内増幅の克服 という高度化の時代を迎えている。これらの技術は基本 的に材料内の残留気孔の除去および極めて高度な粒界の 形成技術に依存している。 また，七ラミックス材料は非 溶融の製造技術であるので, 蛍光イオンなどの不純物偏 析, 固-液界面でのゆらぎがない理由による屈折率変動や 歪みの極めて少ない材料の提供が可能である.さらに は, アイソレーター材料に見られたように焼結技術で光 学グレードの単結晶の製造を行なうことも可能となって おり, 単結晶化のメカニズムが解明されれば様々な材料系 に発展する鬼力がある。このことは前述した高度な粒界 形成からさらに機能付与した界面(すなわち人為的に制御 可能な粒界)の形成へ発展し, 従来の溶融凝固法と焼結法 (セラミックス技術)の材料的境界領域が消滅し, それぞれ のプロセス技術から発生する材料特性を競う時代を予言 するものである。

セラミックス技術は21世紀にレーザーを始めとする高 機能光学用途への展開を迎えようとしている. しかしな がら一方では, 光をキーワードとする材料およびプロセ
ス開発は至難の技術が要求される割にはその成果が報わ れ難く, より市場性の高い材料へ研究者と資金がシフト して行く現実もある。今後は単結晶-セラミックス業界の 技術融合のみならず，高分子，医薬など全くの異業種と の技術連携が新しい材料のコンセプトを生み出し，想像 を越える新機能創製と新市場の形成に結び付くものと考 えられる。

\section{参考文献}

1) T. H. Maiman: Nature 187 (1960) 493.

2) R. L. Coble: J. Appl. Phys. 32 (1961) 793.

3) A. Ikesue, T. Kinoshita, K. Kamata, and K. Yoshida: J. Am. Ceram. Soc. 78 (1995) 1033.

4) I. Shoji, S. Kurimura, Y.Sato, T. Taira, A. Ikesue, and K. Yoshida: Appl. Phys. Lett. 77 (2000) 939.

5) V. Lupei, A. Lupei, S. Georgescu, T. Taira, Y. Sato, and A. Ikesue: Phys. Rev. B 64 (2001) 092102-1.

6) 池末明生：M\&E 7 (2001) 152.

7) C. A. M. Mulder and G. de With: Solid State Ionics 16 (1985) 81.

8) M. Sekita, H. Haneda, T. Yanagitani, and S. Shirasaki: J. Appl. Phys. 67 (1990) 453.

9) 佃康夫：セラミックス 23 (1988) 456.

10) C. Greskovich and K. N. Wood: Am. Ceram. Soc. Bull. 52, 5 (1973) 473.

11) K. Maekawa: FC Report 13 (1995) 303.

12) Y. Sato, I. Shoji, S. Kurimura, T. Taira, and A. Ikesue: OSA TOPOS Vol.22 Advanced Solid State Lasers (2001) in press.

13) 松田 直寿 : セラミックス 28 (1993) 130.

14) C. D. Greskovich, D.Cusano, D. Hoffman, and R. J. Riedner: Am. Ceram Soc. Bull. 71 (1992) 1120.

15) 山田潄道：化学と工業 46 (1993) 606.

16) Y. Ito, H. Yamada, M. Yoshida, H. Fujii, G. Toda, H. Takeuchi, and Y. Tukuda: Jpn. J. Appl. Phys. 27 (1988) L1371.

17) A. Ikesue: J. Ceram. Soc. Jpn. 108 (2000) 1020.

18) C. E. Land and G. H. Haerling: J. Phys. Soc. Jpn. 28 (1970) 96.

19) 一八瀬昇, 平野 䢐一著: 光機能材料セラミックス (オーム 社, 1988 発行) 31 .

20) H. J. Levinstein, S. Light, R. W. Landorf, and S. L. Blank: Appl. Phys. Lett. 19 (1971) 486.

21) 町田博：マテリアルインテグレーション 13 (2000) 43.

22) 特願2000-281682.
透明セラミックス (transparent ceramics)

1950年代後半にR. L. Cobleは透光性アルミナを開発し, 光透過不能とされてきた概念を一変させた。 セラミック スは残留気孔, 未反応物質, 不純物相などの多数の散乱 源により失透するが, 原料純度や焼結性, 焼結速度や雾 囲気などの製造条件を最適化することで散乱を激減させ ることで多結晶材料の透光化を図ることができる。
その後PLZTに代表される様々な透光性セラミックス材料 の開発がなされてきたが，第二のブレークスルーは1993 年の池末らによるレーザー発振可能なYAGセラミックス の開発が挙げられ，単結晶に匹敵する高度な透明化の時 代を迎えている。

(池末 明生) 